\title{
A new species of Ampelisca (Crustacea, Amphipoda) from NW Iberian Peninsula: Ampelisca troncosoi sp. nov.
}

\author{
R. Tato $\cdot$ P. Esquete $\cdot$ J. Moreira
}

Received: 8 June 2011 / Revised: 17 August 2011 / Accepted: 19 August 2011 / Published online: 6 September 2011

(C) Springer-Verlag and AWI 2011

\begin{abstract}
A new species of Ampelisca (Crustacea, Amphipoda) is described from samples collected in shallow subtidal fine and very fine sand in the inlet of Baiona (Galicia, NW Iberian Peninsula). Ampelisca troncosoi sp. nov. is closely related to A. brachyceras and A. heterodactyla by having a rostrum between antenna 1 pair and one lateral angle at each side of the head. The new species may be distinguished by the following combination of characters: a distally rounded rostrum between the antenna 1 pair, one laterodorsal pair of corneal lenses, antenna 1 longer than antenna 2 peduncle, antenna 2 never reaching half of the body length, epimeral plates with rounded posterodistal angle, a prominent rounded urosomal carina and two rows of minute spines on the outer rami of the uropod 3 .
\end{abstract}

Keywords Crustacea $\cdot$ Ampeliscidae $\cdot$ Ampelisca troncosoi sp. nov. A Atlantic $\cdot$ Subtidal $\cdot$ Sediment

Communicated by H.-D. Franke.

R. Tato $(\square) \cdot$ J. Moreira

Estación de Bioloxía Mariña da Graña, Universidad de Santiago de Compostela, Casa do Hórreo, Rúa da Ribeira 1, 15590 A Graña, Ferrol, Spain

e-mail: ramiro.tato@usc.es

P. Esquete

Departamento de Ecoloxía e Bioloxía Animal, Universidade de Vigo, Campus de As Lagoas, 36310 Vigo, Spain

J. Moreira

Departamento de Biología (Zoología), Universidad Autónoma de Madrid, Campus de Cantoblanco, 28049 Madrid, Spain

\section{Introduction}

The family Ampeliscidae is one of the most diverse among the Amphipoda, with more than 230 species described all over the world (Dauvin 1988a; Bellan-Santini and Dauvin 1993), mostly in marine soft bottoms from the intertidal to abyssal depths (Dauvin and Bellan-Santini 1988, 1996). Many species are tube dwellers and may feed as either suspension- or surface deposit-feeders (Enequist 1950; BellanSantini and Dauvin 1988b). Ampeliscids are also important components of benthic assemblages in terms of abundance and secondary production (Dauvin 1988a; Marques and Bellan-Santini 1993; Poggiale and Dauvin 2001), and some species serve as the main source of food for several fishes and gray whales (Wakabara et al. 1982; Franz and Tanacredi 1992; Highsmith and Coyle 1992). Furthermore, species of the genus Ampelisca Krøyer, 1842 are considered to be indicators of quality of sediments and useful to assess the impact of oil spills (Gómez Gesteira and Dauvin 2000; Ramos-Gómez et al. 2009).

The ampeliscid fauna from the NE Atlantic has been exhaustively studied in the last decades, resulting in the description of several new taxa, and life history and ecology of a number of species are now well known (e.g. Bellan-Santini and Dauvin 1981, 1986, 1997, 2008; Dauvin 1988a, b; Dauvin and Bellan-Santini 1988, 1996). The genus Ampelisca is by far the most speciose within the family, with more than 50 species recorded in the NE Atlantic alone (Dauvin and Bellan-Santini 1988, 1996; King et al. 2004); most of these taxa have a distribution restricted to any given biogeographic area or are endemic (Bellan-Santini and Dauvin 1988b). In general, external morphology within the genus is remarkably homogenous, which suggests that speciation is currently occurring and makes it often difficult to distinguish 
Table 1 Coordinates, physical characteristics of the sampling stations and density (ind. $\mathrm{m}^{-2}$ ) of Ampelisca troncosoi sp. nov. at the Ensenada de Baiona

\begin{tabular}{lllllllllll}
\hline Sampling station & 2 & 3 & 5 & 6 & 7 & 9 & 10 & 15 & 17 \\
\hline Latitude (N) & $42^{\circ} 08^{\prime} 50^{\prime \prime}$ & $42^{\circ} 08^{\prime} 50^{\prime \prime}$ & $42^{\circ} 08^{\prime} 30^{\prime \prime}$ & $42^{\circ} 08^{\prime} 30^{\prime \prime}$ & $42^{\circ} 08^{\prime} 30^{\prime \prime}$ & $42^{\circ} 08^{\prime} 10^{\prime \prime}$ & $42^{\circ} 08^{\prime} 10^{\prime \prime}$ & $42^{\circ} 07^{\prime} 50^{\prime \prime}$ & $42^{\circ} 07^{\prime} 30^{\prime \prime}$ & $42^{\circ} 07^{\prime} 30^{\prime \prime}$ \\
Longitude (W) & $08^{\circ} 50^{\prime} 15^{\prime \prime}$ & $08^{\circ} 49^{\prime} 44^{\prime \prime}$ & $08^{\circ} 50^{\prime} 15^{\prime \prime}$ & $08^{\circ} 49^{\prime} 44^{\prime \prime}$ & $08^{\circ} 49^{\prime} 13^{\prime \prime}$ & $08^{\circ} 50^{\prime} 15^{\prime \prime}$ & $08^{\circ} 49^{\prime} 44^{\prime \prime}$ & $08^{\circ} 49^{\prime} 13^{\prime \prime}$ & $08^{\circ} 50^{\prime} 15^{\prime \prime}$ & $08^{\circ} 49^{\prime} 44^{\prime \prime}$ \\
Depth (m) & 7.0 & 4.0 & 11.0 & 7.0 & 3.0 & 10.0 & 8.0 & 4.0 & 7.0 & 8.0 \\
$Q_{50}(\mathrm{~mm})$ & 0.135 & 0.088 & 0.092 & 0.093 & 0.146 & 0.350 & 0.140 & 0.140 & 0.230 & 0.230 \\
$S_{\text {o }}$ & 1.6 & 1.3 & 1.3 & 1.3 & 1.4 & 1.4 & 1.6 & 1.5 & 1.7 & 1.5 \\
Gravel (\%) & 3.5 & 0.0 & 0.1 & 0.1 & 0.0 & 1.2 & 5.8 & 0.0 & 9.6 & 2.1 \\
Very coarse sand (\%) & 2.1 & 0.1 & 0.2 & 0.2 & 0.0 & 6.3 & 3.2 & 0.1 & 4.9 & 2.6 \\
Coarse sand (\%) & 2.4 & 0.1 & 0.6 & 0.5 & 0.2 & 15.7 & 1.8 & 0.9 & 6.9 & 6.1 \\
Medium sand (\%) & 9.7 & 0.3 & 3.1 & 1.5 & 5.1 & 51.3 & 4.4 & 3.7 & 22.2 & 33.2 \\
Fine sand (\%) & 36.2 & 6.8 & 11.5 & 12.0 & 53.1 & 21.1 & 39.4 & 50.7 & 40.4 & 47.1 \\
Very fine sand (\%) & 39.6 & 79.8 & 73.0 & 76.4 & 37.9 & 1.3 & 40.2 & 40.3 & 9.7 & 5.0 \\
Silt/clay (\%) & 6.5 & 12.8 & 11.4 & 9.3 & 3.5 & 3.1 & 5.2 & 4.1 & 6.2 & 3.8 \\
Calcium carbonate (\%) & 32.4 & 29.7 & 34.4 & 37.6 & 48.3 & 82.7 & 49.1 & 45.0 & 72.9 & 75.3 \\
TOM (\%) & 1.9 & 2.3 & 1.7 & 2.1 & 2.1 & 2.3 & 2.2 & 2.3 & 3.2 & 2.5 \\
Density (ind. m ${ }^{-2}$ ) & 42.9 & 46.4 & 114.3 & 21.4 & 10.7 & 3.6 & 57.1 & 17.9 & 14.3 & 25.0 \\
\hline
\end{tabular}

$Q_{50}$, grain-size median, $S_{0}$ sorting coefficient, TOM total organic matter

among closely related species (Bellan-Santini and Dauvin 1988a; Dauvin and Bellan-Santini 1988); recent attempts have tried to review which characters may result reliable in the determination of species and to clarify the status of some close species (e.g. Dauvin and Bellan-Santini 1988; Myers and McGrath 1991; King et al. 2004).

Ampelisca species are frequently found coexisting in the same sediments in the NE Atlantic (Dauvin 1988a), which suggests that there is few overlapping for trophic resources (Bellan-Santini and Dauvin 1988b). This phenomenon also occurs in the Galician rias (NW Iberian Peninsula), mostly on fine and muddy sands (Garmendia et al. 1998; Lourido et al. 2008). Examination of samples collected between 1995 and 1997 in the soft bottoms of the Ensenada de Baiona (Galicia, NW Iberian Peninsula) yielded seven coexisting ampeliscid species belonging to the genus Ampelisca. Among these, one is new to science and is described herein as Ampelisca troncosoi sp. nov.

\section{Materials and methods}

Specimens of Ampelisca troncosoi sp. nov. were collected at the Ensenada de Baiona (Galicia, NW Iberian Peninsula), within the frame of several sampling programs, between 1995 and 1997. This inlet is located in the south margin of the Ría de Vigo $\left(42^{\circ} 07^{\prime} \mathrm{N}-42^{\circ} 09^{\prime} \mathrm{N}\right.$, $08^{\circ} 51^{\prime} \mathrm{W}-08^{\circ} 49^{\prime} \mathrm{W}$ ) with maximal depths of $12-15 \mathrm{~m}$ in the mouth; seawater shows a salinity ranging between 32 and $35 \%$ in the outer area and 28 and 35\%o in the inner harbor area. Sampling in December 1995 was done in 21 subtidal sites, ranging from gravel to mud (see Moreira et al. 2008a for details); further monthly sampling was done in three of those sites (fine sand to very fine sand) from February 1996 to February 1997 (Moreira et al. 2008b, 2010). Samples were taken using a Van Veen grab, sieved through $0.5-\mathrm{mm}$ mesh; specimens were fixed in 5\% formaldehyde, rinsed with freshwater and then preserved in $70 \%$ ethanol.

Line drawings of the holotype and three dissected adult males were done with the aid of a camera lucida connected to a compound microscope and prepared for their final format with the graphic design program Corel Draw Graphics Suite X5. Specimens used for scanning electron microscope (SEM) were previously frozen with liquid nitrogen, dehydrated via lyophilization, and examined and photographed with an EVO LS 15 scanning electron microscope at the Unidade de Microscopía Electrónica, Universidade de Santiago de Compostela (UME-USC), Spain. The total length (TL) was measured from the distal part of the head to the posterior end of urosomite 3. Type series are deposited in the Museo Nacional de Ciencias Naturales, Madrid (MNCN) and Zoological Museum Hamburg (ZMH); other specimens are kept in the collection of the authors at the Estación de Bioloxía Mariña da Graña (EBMG-USC). 


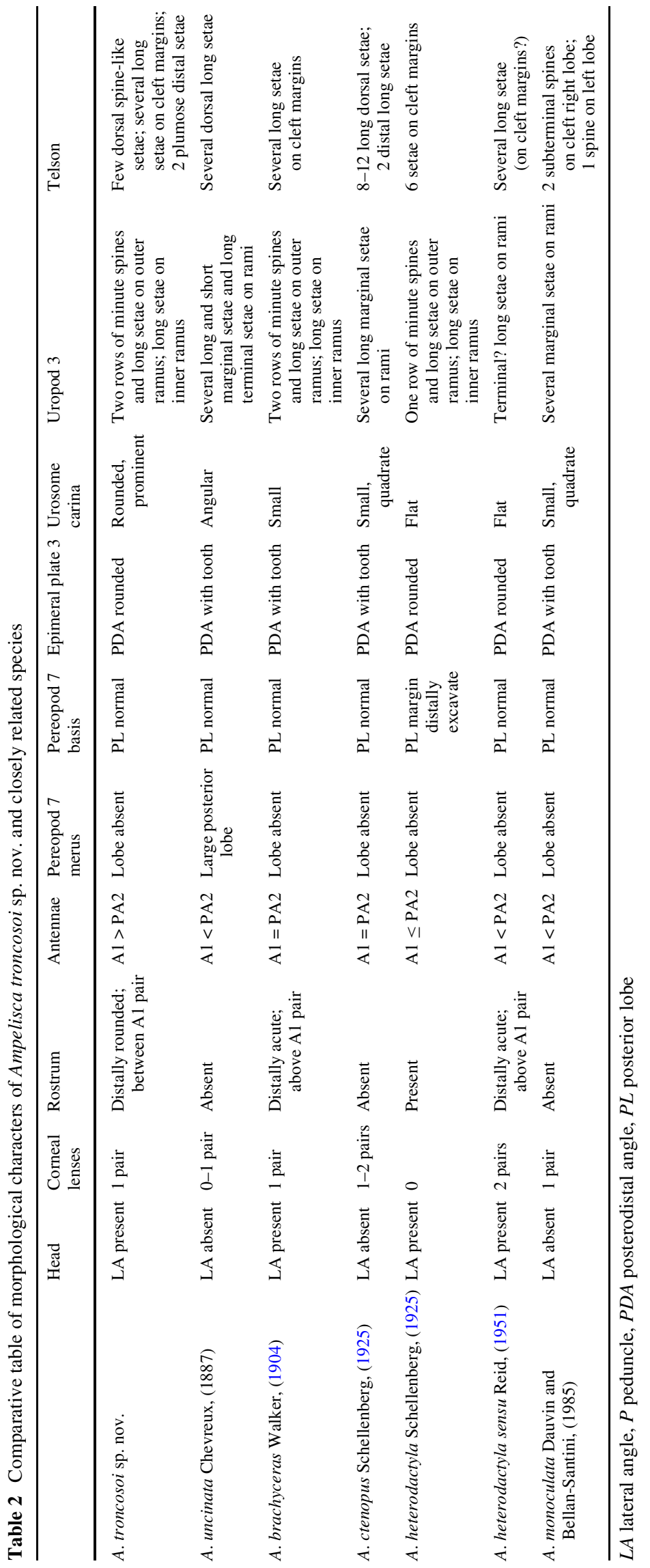


Fig. 1 Ampelisca troncosoi $\mathrm{sp.}$ nov. a Holotype, adult $\hat{\alpha}$, lateral view. b Allotype, adult + , lateral view. c $\hat{\sigma}$, Antenna $1 . \mathbf{d} \hat{\sigma}$, Antenna 2. e $\circ$, Antenna 2. f $\hat{\jmath}$, Epimeral plates 1-3. Scale bar $\mathbf{a}$, b $1 \mathrm{~mm}$; c-e $0.25 \mathrm{~mm} ; \mathbf{f} 1 \mathrm{~mm}$

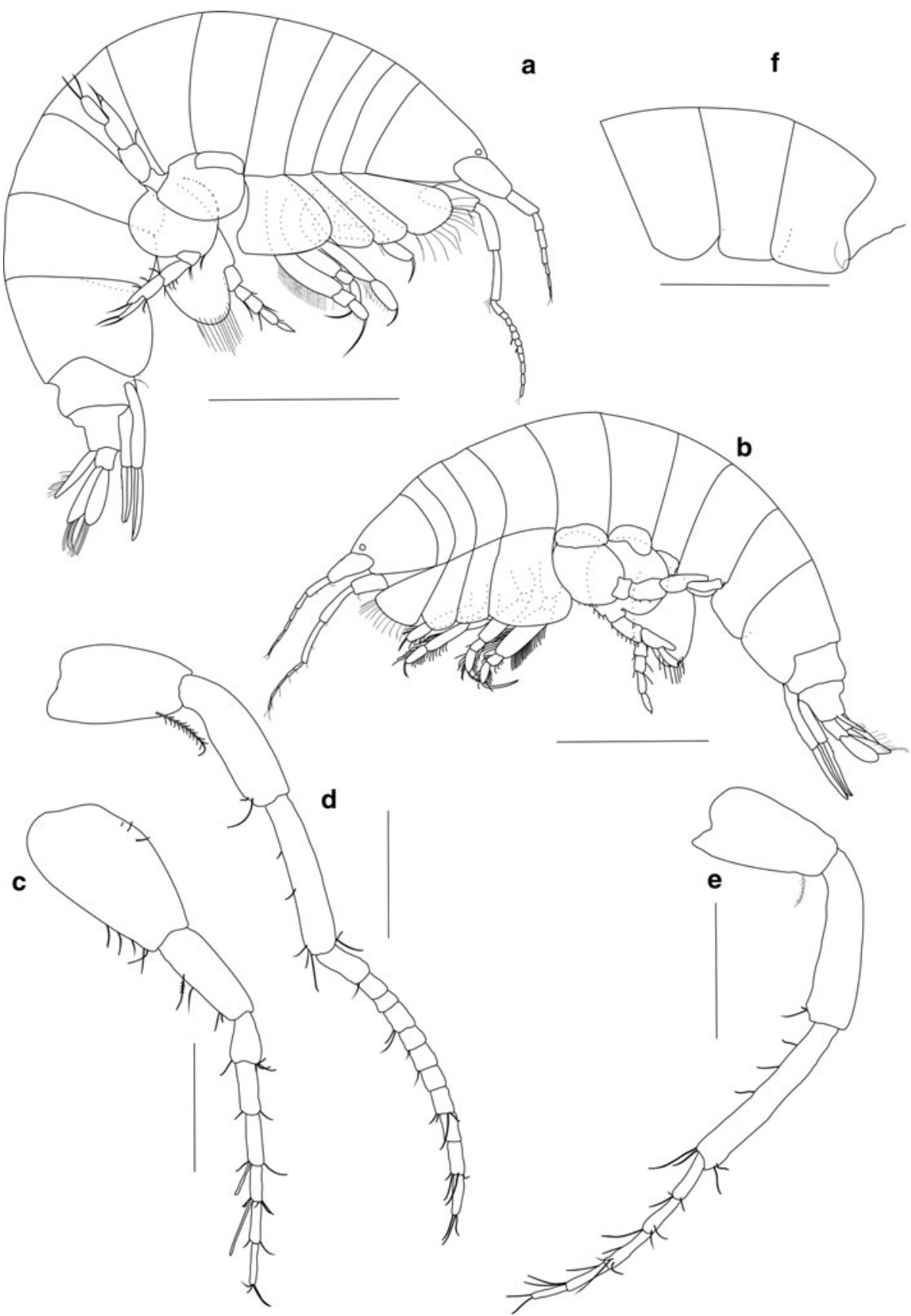

\section{Results}

Family Ampeliscidae Costa, 1857

Genus Ampelisca Krøyer, 1842

Ampelisca troncosoi sp. nov. (Tables 1, 2; Figs. 1, 2, 3, 4, $5,6,7,8)$.

Ampelisca sp.- Moreira et al. 2008a, b.

Type material Holotype: $\hat{\jmath}$, TL 4.15 mm, Est. 15 (MNCN 20.04/8668). Allotype: ㅇ, TL $4.43 \mathrm{~mm}$, St. 15 (MNCN 20.04/8669). Paratypes: $\widehat{\jmath}$, 4웅, St. 2 (MNCN 20.04/8670);

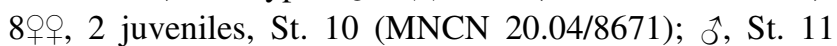

(MNCN 20.04/8672); ㅇ, St. 15 (MNCN 20.04/8673); 4우, St. 17 (MNCN 20.04/8674); + , St. 18 (MNCN 20.04/8675); o, 4우우, St. 17 (ZMH K-42962).

Type locality Ensenada de Baiona, Ría de Vigo (NW Iberian Peninsula).

Etymology We named this species after Dr. Jesús S. Troncoso (Universidade de Vigo) in regard to his friendship along all these years.

Diagnosis Head as long as broad, conical, with distally rounded rostrum; one laterodistal angle on each side of head; one pair of subdistal laterodorsal corneal lenses; first article of 
Fig. 2 Ampelisca troncosoi $\mathrm{sp}$. nov. $\widehat{\jmath}$. a Head. b Left mandible, detail. c Right mandible, detail. d Maxilla 2. e Mandible (only long setae on palp inner margin represented as plumose).

f Maxilliped, palp (only long setae on outer margin represented as plumose). $\mathbf{g}$ Maxilliped.

h Maxilla 1.i Compound spines. j Coxal plates 1-3. k Lower lip. Scale bar a $0.25 \mathrm{~mm}$; b-h,

k $0.1 \mathrm{~mm} ; \mathbf{i} 0.05 \mathrm{~mm} ; \mathbf{j} 1 \mathrm{~mm}$
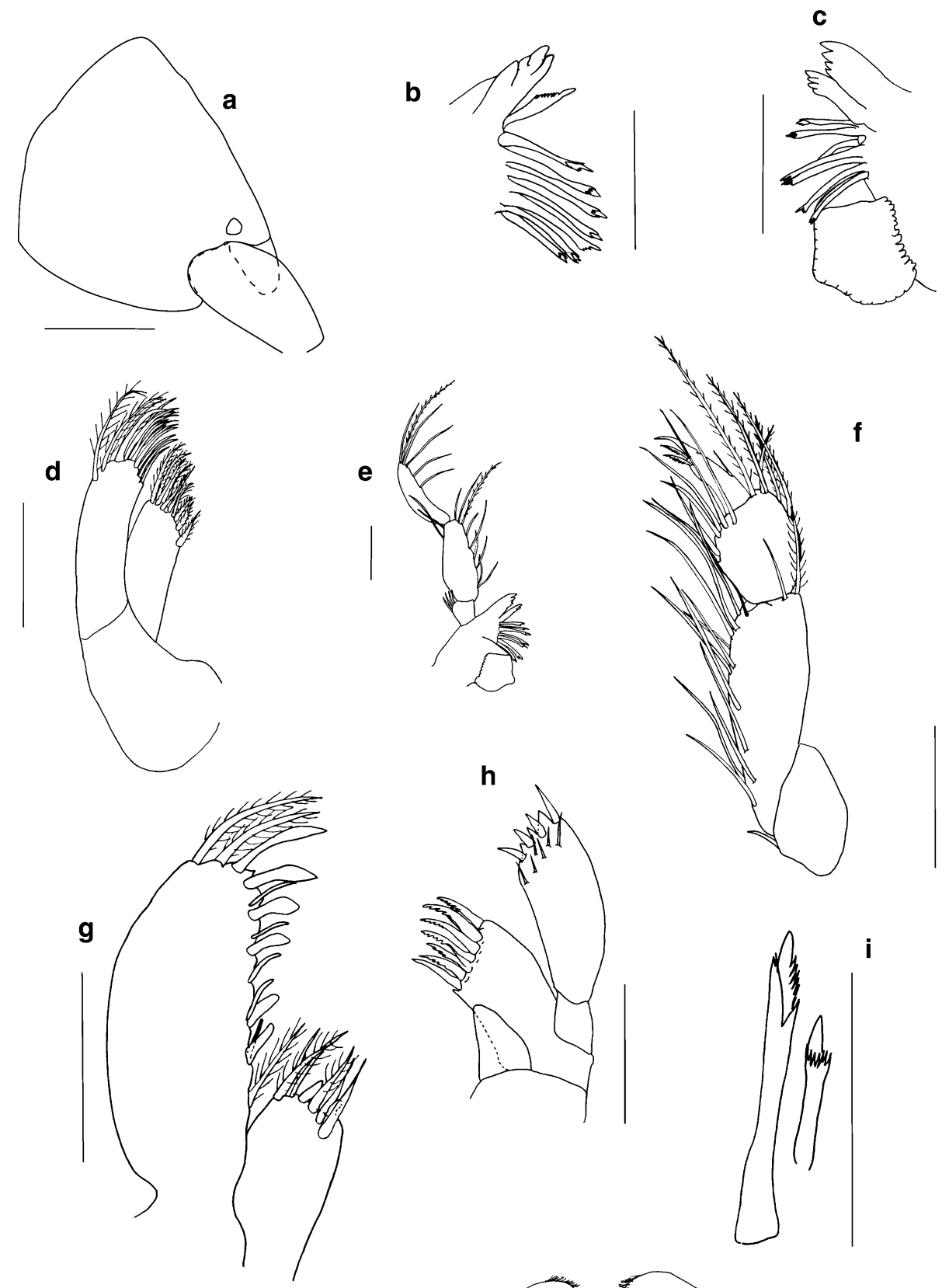

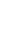

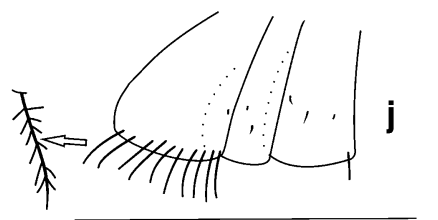

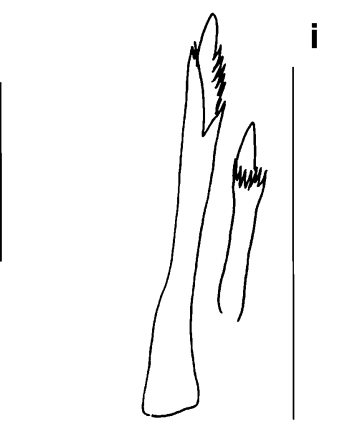
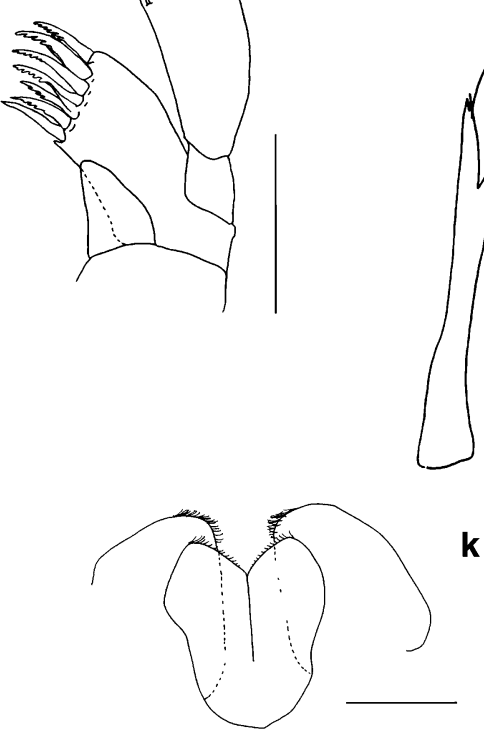

antenna 1 peduncle wider at proximal margin and 1.3 times longer than second article; antenna 1 longer than antenna 2 peduncle; antenna 2 less than half body length; pereopod 4 merus 3.1 times as long as broad; pereopod 4 dactylus longer than propodus and carpus combined; pereopod 7 basis posteroventral margin lobe broadly rounded, reaching half-length of carpus; pereopod 7 merus not distally produced, shorter than ischium; epimeral plate 3 posteroventral corner rounded, not ending in acute tooth; uropod 1 reaching or surpassing uropod 2 distal end and reaching uropod 3 distal end; uropod 1 outer ramus lacking robust setae; uropod $1-3$ rami subequal; uropod 3 outer ramus with two parallel rows of triangular, minute spines along outer margin distal half; telson cleft at $2 / 3$ of length, each lobe bearing several distally curved setae along inner margin and one terminal plumose seta; telson dorsal surface with a few spine-like setae. 
Fig. 3 Ampelisca troncosoi sp. nov. ô. a Gnathopod 1. b Gnathopod 2. c Pereopod 3. d Pereopod 4. e Pereopod 5. f Pereopod 6. g Pereopod 7. Scale bar $0.25 \mathrm{~mm}$

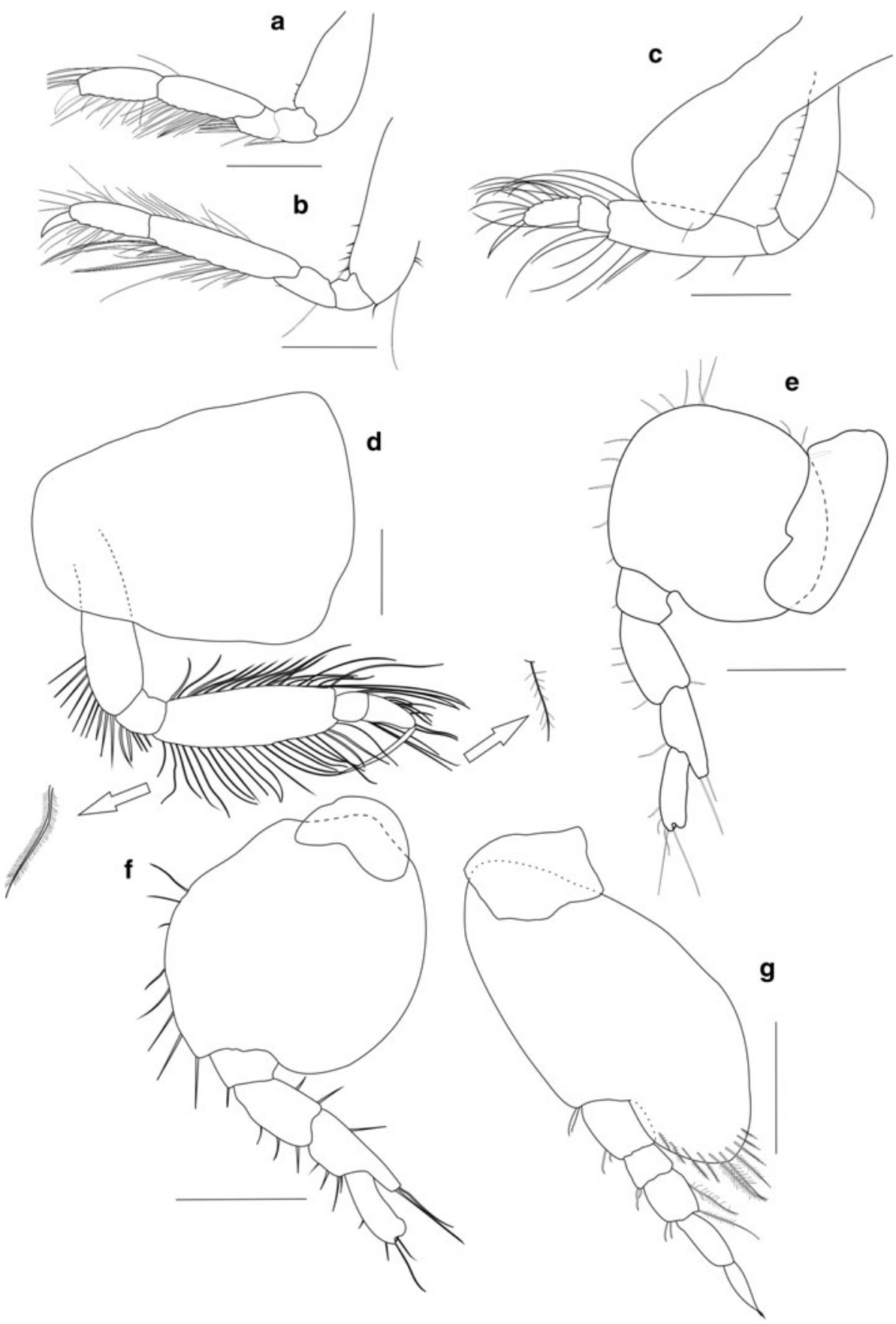

Description of the male holotype

Head Longer than deep, conical, subequal in length to pereon segments 1-3 combined (Fig. 1a); laterodistal rounded angle defined by insertion of antenna 1 peduncle; inferior margin gently convex posteriorly (Fig. 2a). Short rostrum between antenna 1 pair, distally rounded, never exceeding half-length of first article of antenna 1 peduncle (Fig. 5b). One pair of subdistal laterodorsal corneal lenses, near insertion of antenna 1 peduncle.
Antenna 1 Longer than antenna 2 peduncle, reaching at least distal end of flagellum proximal third; 2-articled peduncle (Fig. 1c); flagellum with 6 articles. Peduncle first article wider at proximal margin and narrower at distal margin. Second article cylindrical, 0.7 times as long as first article. Ventral margin of peduncle articles 1-2 and distal margin of flagellum articles with short setae; ventral margin of peduncle article 2 with one plumose seta and a subdistal small row of short setae. Aesthetascs present on flagellum articles 3-4 distal margin. 


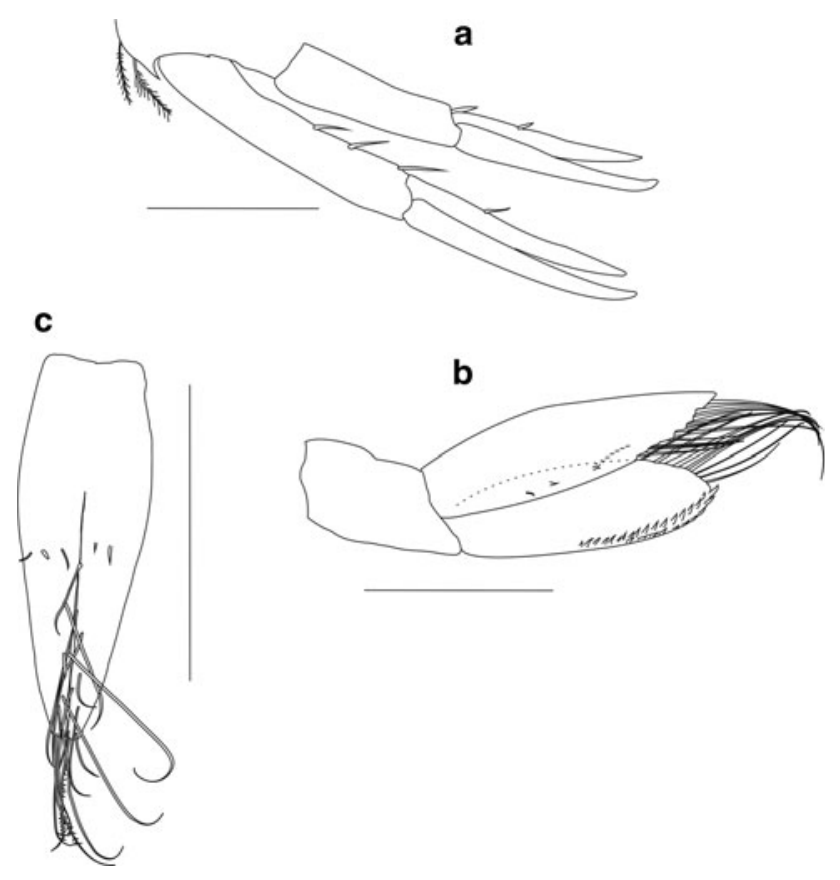

Fig. 4 Ampelisca troncosoi sp. nov. §ิ. a Uropods 1-2, lateral view. b Uropod 3, lateral view. c Telson, dorsal view. Scale bar $0.25 \mathrm{~mm}$

Antenna 2 Less than half body length; peduncle 3-articled (Fig. 1d); flagellum with 11 articles. Peduncle first article wider at proximal margin and narrower at distal margin; ventral margin with one plumose seta. Second article elongated with a ventral curvature along proximal third. Third article thinner and about as long as second. Distal margin of peduncle third article and flagellum articles with short paired setae.

Mandible Molar broad, well developed, spine-row of 7 composite spines between molar and lacinia mobilis, incisor with 4 teeth (Fig. 2b, c). Right and left lacinia mobilis with 4 and 7 teeth, respectively. Mandibular palp 3-articled (Fig. 2e); first article short, dorsal margin with setae; articles 2-3 subequal in length, about 3 times as long as first article, inner margin with plumose setae; second article broader than third; third article outer margin convex, inner margin slightly concave.

Maxilla 1 Inner plate without seta (Fig. 2h); outer plate with 7 spines serrated along inner margin; palp with distal margin bearing 3 acute cusps, 4 spines and row of six subdistal setae.

Maxilla 2 Inner plate with 2 long curved plumose setae and numerous smooth setae on distal margin (Fig. 2d); outer plate with plumose setae of decreasing length.

Maxilliped Inner plate small and rounded with one thick short spine, 2 plumose setae and several smooth setae
(Fig. 2g). Outer plate reaching palp third article, with 2 distal plumose setae and inner margin with 8 chisel-shaped robust setae alternating with thinner, shorter setae. Palp typical of genus, 4-articled, inner margin of all articles and outer distal margin of articles 2-3 with numerous plumose setae (Fig. 2f). Lower lip typical of genus (Fig. 2k).

Coxal plates Plates 1-3 with anterodistal margin rounded (Fig. 2j). Plate 1 distal margin expanded, broader than that of plates 2-3, with a row of plumose setae on distal margin. Plates 2-3 with few small setae on lateral margin. Plate 4 large, broader, with posterodistal margin posteriorly expanded. Coxal plates 5-7 reduced.

Gnathopods 1-2 Typical of genus (Fig. 3a, b). Two different types of plumose setae present: densely plumose (especially on basis, ischium and merus) and sparsely plumose (mostly on carpus and propodus) (Figs. 3d, 5c, d). Basis elongated, distally inflated; anterodistal margin with short setae. Gnathopod 2 basis distal margin with a few long plumose setae, posterodistal margin with a few short setae. Ischium and merus reduced; carpus elongated; propodus slightly oval with serrated inferior margin at distal third; dactylus well developed, shorter than propodus. Carpus and propodus with plumose setae; gnathopod 2 merus with smooth setae.

Pereopods 3-4 Typical of genus (Fig. 3c, d). Basis elongated, inflated, with numerous long plumose setae on pereopod 4; ischium and carpus reduced; merus well developed, about 3.2 (P3)-3.1 (P4) times as long as wide; pereopod 3 propodus with serrated dorsal margin; pereopod 3 dactylus as long as propodus; pereopod 4 dactylus long and slender, subequal or longer than carpus and propodus combined.

Pereopod 5 Basis rounded, broader than long, with setae along anterior and dorsal margins (Fig. 3e); ischium reduced; carpus with one elongated lobe on posterodistal margin, about $1 / 3$ of propodus length, provided with 2-3 comb-like setae on distal margin (Fig. 5e, f); dactylus short, rudimentary. Merus, carpus and propodus with few setae on anterior margins; propodus with 2 long setae on distal margin.

Pereopod 6 Appearance of articles similar to that of pereopod 5 (Fig. 3f). Basis slightly oval, slightly broader than long, with fewer setae than pereopod 5 , restricted to anterior margin; merus, carpus and propodus with setae on anterior margins and fewer setae on posterior margins; carpus with few setae on terminal elongated lobe; dactylus short, rudimentary.

Pereopod 7 Basis well developed, longer than broad (Fig. 3g); posterior lobe reaching carpus and overlapping ischium posterior margin, with row of densely plumose 

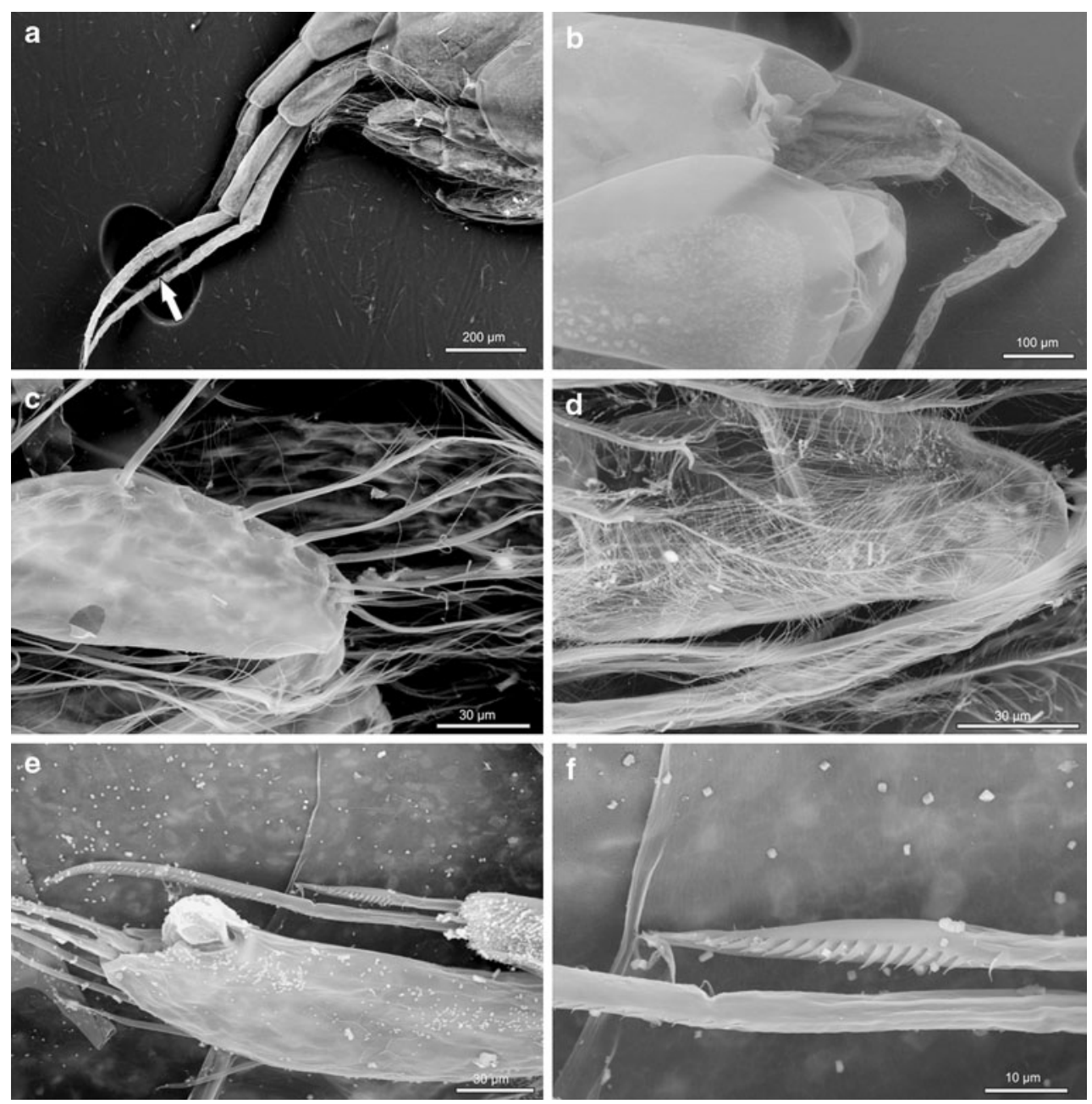

Fig. 5 Ampelisca troncosoi sp. nov. §ิ, SEM micrographs. a Antennae 1-2 (arrow marks end of antenna 1 flagellum). b Head, rostrum, detail. c Pereopod 3, sparsely plumose setae. d Pereopod 4, densely plumose

setae. e Pereopod 5, carpus, comb-like setae. f Pereopod 5, carpus, comb-like seta, detail

setae on distal margin. Merus shorter than ischium and carpus, not distally produced; propodus slightly longer than carpus; dactylus well developed, slightly shorter than propodus. Ischium, merus and carpus with small setae on distal anterior margins; 2 sparsely plumose long setae on carpus posterior margin.

Pleon Epimeral plates with smooth posterior margin, lacking curls or tooth-shaped processes (Fig. 1f). Plates 1-3 posterodistal angle rounded; plate 3 with posterior margin concave.

Urosome Urosomite 1 with prominent rounded carina along dorsal posterior margin; one curved tooth-shaped process on inferior posterior margin near uropod 1 peduncle, with 2 subdistal plumose setae (Fig. 4a). Urosomites 2-3 with rounded carina along dorsal proximal margin, dorsal posterior margin straight.

Uropods Uropod 1 peduncle elongated, posterodistal margin with 3 thin spines; rami subequal in length, sur-

passing distal end of uropod 2; proximal third of inner ramus posterodistal margin with one short spine. Uropod 2 similar to first pair but shorter; rami subequal; inner ramus posterior margin with 2 short spines: one near peduncle and one on distal end of proximal third (Fig. 4a). Uropods 1 and 2 peduncle and rami dorsal margin with a row of minute teeth (Fig. 6a, b). Uropod 3 peduncle short (Fig. 4b); rami subequal; outer ramus with two parallel rows of triangular, minute spines along outer margin distal half and long setae on inner margin (Fig. 6c); inner ramus distal outer margin serrulated, with numerous curved setae and few short spines on medial margin (Fig. 6d); inner ramus dorsal margin minutely fringed (Fig. 6e, f).

Telson Three times as long as wide, with several dorsal short spine-like setae at mid-length; telson cleft about $2 / 3$ of total length defining two long, triangular lobes, with distal margins rounded; each lobe bearing several distally 

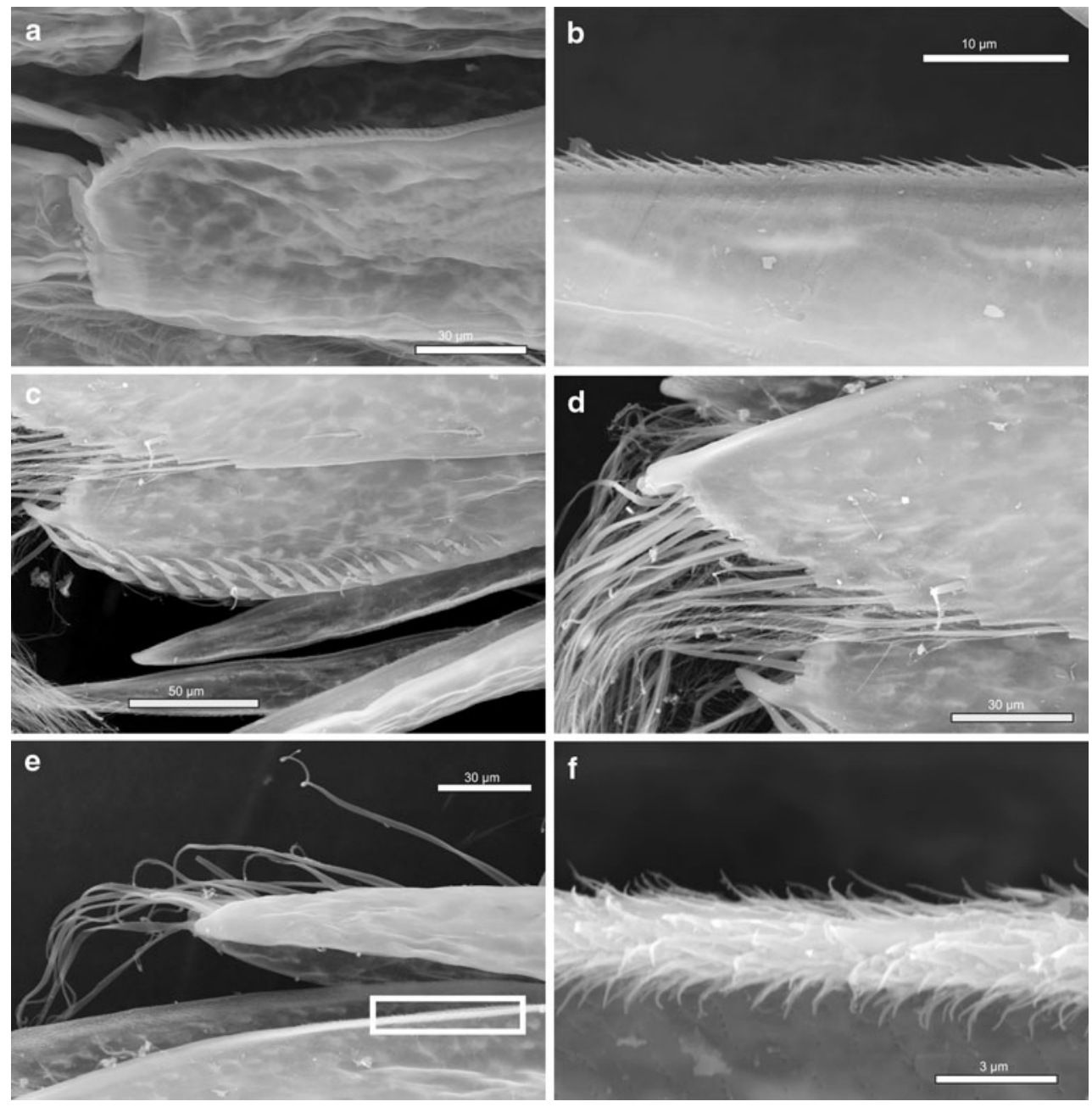

Fig. 6 Ampelisca troncosoi sp. nov. ô, SEM micrographs. a Uropod 1, peduncle, dorsal margin, detail. b Uropod 1, ramus, dorsal margin, detail. c Uropod 3, outer ramus, detail. d Uropod 3, inner ramus, detail.

curved setae along inner margin and one terminal plumose seta (Fig. 4c).

\section{Sexual dimorphism}

Males and females are very alike in appearance; sexual dimorphism is mostly detected because of the presence of oostegites in females, the length of antenna 2 and the shape of the urosome carina. In adult males, the flagellum of the antenna 2 bears shorter, broader and more numerous articles than that of females ( 30 : 8-11, 우우: 5-6; Fig. 1e) and the urosome carina is larger. Appendages show a high variability in number, size and surface covered by setae, and therefore, these features are not reliable for sexual identification.

\section{Intraspecific variation}

The flagellum of the antenna 1 bears between 5 and 7 articles depending on the developmental stage of the specimen.

e Telson and uropod 3 inner ramus (square highlights area enlarged in f). f Uropod 3, inner ramus, dorsal margin, detail

The size and shape of the aesthetascs is variable between adult individuals and hardly visible in juveniles. The number of plumose setae near the curved tooth-shaped process on urosomite may vary between 1 and 3 . The juveniles are mostly similar to females, but there are fewer articles on antenna $1-2$, fewer setae on pereopods, and the urosome carina is absent or less developed.

\section{Ecology}

Ampelisca troncosoi sp. nov. was found in shallow subtidal fine and very fine sand at the Ensenada de Baiona (grainsize median, $Q_{50}: 0.09-0.23 \mathrm{~mm}$; depth: $2-12 \mathrm{~m}$ ), with a total organic matter content ranging between 1.7 and $3.2 \%$ and that of calcium carbonate between 30 and $75 \%$; only one specimen was found in a medium sand bottom $\left(Q_{50}\right.$ : $0.35 \mathrm{~mm}$ ). The new species coexists with up to other six ampeliscids in the studied area, namely A.brevicornis (Costa, 1853), A.tenuicornis Liljeborg, 1855, A.typica 


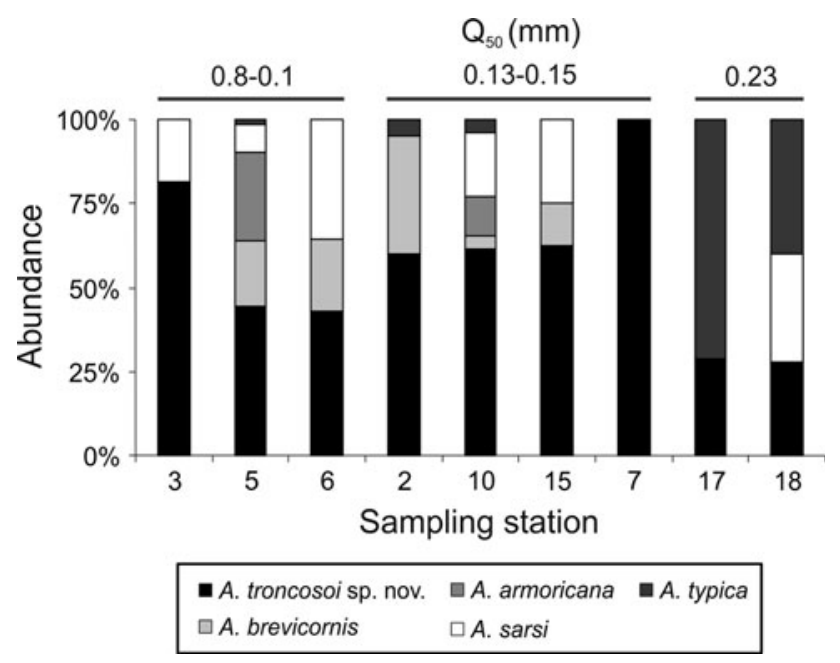

Fig. 7 Abundance (\%) of Ampelisca troncosoi sp. nov. and coexisting Ampelisca species in the Ensenada de Baiona according to sampling site and grain-size median $\left(Q_{50}\right)$

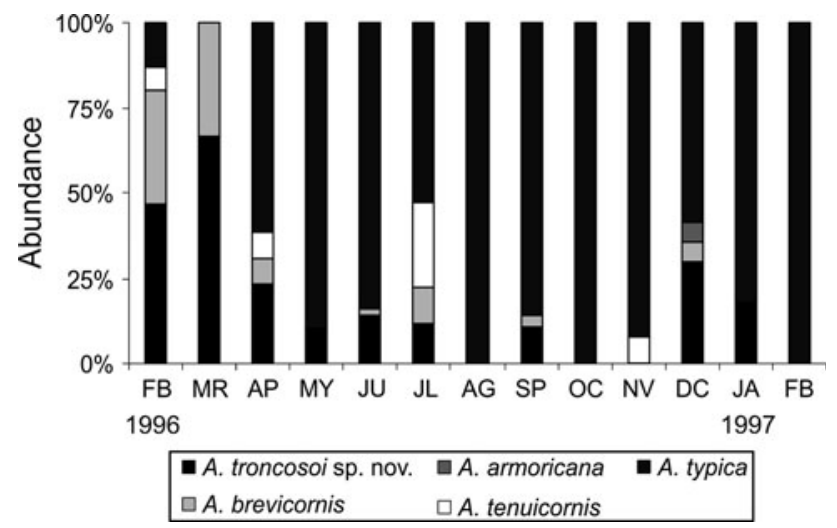

Fig. 8 Monthly abundance (\%) of Ampelisca troncosoi sp. nov. and coexisting Ampelisca species in Station 17 at the Ensenada de Baiona

(Bate, 1856), A. spinipes Boeck, 1860, A. sarsi Chevreux, 1887 and A. armoricana Bellan-Santini and Dauvin, 1981. Ampelisca troncosoi sp. nov. was, in general, the most abundant species of the genus in finer sandy sediments where medium sand content was lower than $10 \%$ and $Q_{50}$ was between 0.8 and $0.15 \mathrm{~mm}$ (Table 1; Fig. 7); Ampelisca typica (Bate, 1856) was, however, the dominant ampeliscid in two fine sand sites (St. 17 and 18) where medium sand content was higher $(20-30 \%)$. A monthly study of three sandy stations (St. 2, 15, 17) showed that A.troncosoi sp. nov. was present at St. 17 for most of the year (Fig. 8) and sparsely present at stations 2 and 15 (not shown).

\section{Remarks}

Ampelisca troncosoi sp. nov. is unique among the other species of the genus due to the following combination of characters: a distally rounded rostrum between the antenna 1 pair, only one laterodorsal pair of corneal lenses, antenna 1 longer than the peduncle of antenna 2 , antenna 2 never reaching half of the body length, epimeral plates with rounded posterodistal angle, a prominent rounded urosomal carina, a curved tooth-shaped process on each side of the posteroventral margin of urosomite 1 , two rows of minute spines on the outer rami of the third uropod and a pereopod 7 with basis reaching carpus. Among the species reported from the NE Atlantic (Dauvin and Bellan-Santini 1988), only three of them may bear a single pair of corneal lenses, namely A. uncinata Chevreux, 1887, A. ctenopus Schellenberg, 1925 and A. monoculata Dauvin and Bellan-Santini, 1985. These species differ mostly from the new species in having an antenna 1 as long as or shorter than the peduncle of the antenna 2, an epimeral plate 3 with a tooth on the posterodistal angle and an angular-quadrate carina in the urosome instead of a rounded one (Table 2). Ampelisca troncosoi sp. nov. is mostly related to A.brachyceras Walker, 1904 from the Indian Ocean and A. heterodactyla Schellenberg, 1925 from West Africa in having short antennae, a posterior distal lobe on the carpus of the pereopods $5-6$, the appearance and distribution of setae on uropod 3, and, particularly, by an unusual head shape, characterized by presenting a short rostrum and one rounded laterodistal angle on each side determining well-defined lobes (cfr. Walker 1904; Fig. 13c). Reid (1951) suggested that the two aforementioned species may constitute a distinct genus, but this has not been supported by phylogenetic analysis yet (Bellan-Santini and Dauvin 1988a). Ampelisca heterodactyla has been reported in the Iberian Peninsula from SW Portugal (Marques and Bellan-Santini 1991) and the Basque Country (Martínez and Adarraga 2003; Martínez et al. 2007), and it has been suggested that this species may have been introduced there as a result of human activities. However, A. brachyceras differs mainly from A.troncosoi sp. nov. in having a rostrum distally acute instead of being rounded, a posterodistal margin of the epimeral plate 3 produced in a tooth, an uropod 1 with the peduncle much longer than the rami and a small urosomal carina instead of being rounded and prominent. On the other hand, in A. heterodactyla, the corneal lenses are lacking, the antenna 1 is at most as long as the peduncle of the antenna 2, the pereopod 4 dactylus is proportionally longer, the posterior margin of the pereopod 7 basis is distally excavate, the outer margin of the uropod 3 outer rami is provided with one row of minute spines instead of two, the urosomal carina is flat and the dorsal surface of the telson lacks spinelike setae (Schellenberg 1925). The specimens of A. heterodactyla from tropical West Africa described by Reid (1951; cfr. Fig. 16) differ from the original description of the species in a number of features: two pairs of corneal lenses are present, the pereopod 4 dactylus is about as long 
as propodus and carpus combined, and the pereopod 7 basis is not distally excavate; they also resemble A. brachyceras in the appearance of the rostrum, which is distally acute, but differ mostly from the latter in the shape of the epimeral plate 3. Whether these specimens represent a different species or are within the intraspecific variation of A. heterodactyla, they differ from A. troncosoi sp. nov. in the number of corneal lenses, the shape of the rostrum and urosomal carina, and the relative length of the dactylus to that of propodus-carpus in pereopod 4. Anyway, it seems that a complex of closely related/sibling species including A. brachyceras, A. heterodactyla, A. troncosoi sp. nov. and possibly other undescribed taxa (Reid 1951) are distributed along neritic waters from the Indian Ocean to southern Europe; future taxonomic and molecular work will help to clarify the phylogenetic relationships among these species and within the genus Ampelisca.

Acknowledgments The authors are grateful to the members of the laboratory of Adaptaciones de Animales Marinos (Universidade de Vigo) for their invaluable help in the collecting of the specimens. Special thanks to Marcos Abad and Victoriano Urgorri (EBMG-USC) and Raquel Antón (UME-USC) by their assistance in preparing and examining the samples for SEM studies, and to Julia García-Carracedo for translating some bibliographic references and correcting the English version of the manuscript. Three anonymous referees provided constructive comments that helped to improve the final version of the manuscript. This work was partly done at the Estación de Bioloxía Mariña da Graña (USC).

\section{References}

Bellan-Santini D, Dauvin JC (1981) Description d'une nouvelle espèce d'Ampelisca des côtes françaises (Amphipoda). Crustaceana 40(3):243-252

Bellan-Santini D, Dauvin JC (1986) Ampelisca remora (Amphipoda): Nouvelle espèce des côtes de Galice (Atlantique Nord-Est). Crustaceana 51(1):39-48

Bellan-Santini D, Dauvin JC (1988a) Actualisation des donnees sur l'ecologie, la biogeographie et la phylogenie des Ampeliscidae (Crustaces-Amphipodes) atlantiques après la revision des collections d'E. Chevreux. Actes de Colloques, Institut Français d'Exploitation de la Mer 8:207-216

Bellan-Santini D, Dauvin JC (1988b) Éléments de synthèse sur les Ampelisca du Nord-est Atlantique. Crustaceana Suppl 13:27-67

Bellan-Santini D, Dauvin JC (1993) Distribution and phylogeny of the genus Byblis Boeck (Ampeliscidae): preliminary statement. J Nat Hist 27:909-931

Bellan-Santini D, Dauvin JC (1997) Ampeliscidae (Amphipoda) from Iceland with a description of a new species (contribution to the BIOICE research programme). J Nat Hist 31:1157-1173

Bellan-Santini D, Dauvin JC (2008) Contribution to knowledge of the genus Haploops, a new location for Haploops lodo (Crustacea: Amphipoda: Ampeliscidae) from the bathyal North Atlantic Ocean with a complement to the description of the species. J Nat Hist 42:1065-1077

Dauvin JC (1988a) Biologie, dynamique, et production de populations de crustacés amphipodes de Manche occidentale. 1. Ampelisca tenuicornis Liljeborg. J Exp Mar Biol Ecol 118:55-84
Dauvin JC (1988b) Life cicle, dynamics, and productivity of Crustacea-Amphipoda from the western English channel. 4. Ampelisca armoricana Bellan-Santini et Dauvin. J Exp Mar Biol Ecol 123:235-252

Dauvin JC, Bellan-Santini D (1988) Illustrated key to Ampelisca species from the North-eastern Atlantic. J Mar Biol Ass UK 68:659676

Dauvin JC, Bellan-Santini D (1996) Ampeliscidae (Amphipoda) from the Bay of Biscay. J Crust Biol 16(1):149-168

Enequist P (1950) Studies on the soft-bottom amphipods of the Skagerak. Zool Bidrag Fran Uppsala 28:297-492

Franz DR, Tanacredi JT (1992) Secondary production of the amphipod Ampelisca abdita Mills and its importance in the diet of juvenile winter flounder (Pleuronectes americanus) in Jamaica Bay, New York. Estuaries 15(2):193-203

Garmendia JM, Sánchez-Mata A, Mora J (1998) Inventario de la macrofauna bentónica de sustratos blandos submareales de la Ría de Ares y Betanzos (NO de la Península Ibérica). Nova Acta Científica Compostelana (Biol) 8:209-231

Gómez Gesteira JL, Dauvin JC (2000) Amphipods are good bioindicators of the impact of oil spills on soft-bottom macrobenthic communities. Mar Poll Bull 40:1017-1027

Highsmith RC, Coyle KO (1992) Productivity of arctic amphipods relative to gray whale energy requirements. Mar Ecol Prog Ser 83:141-150

King RA, Myers AA, McGrath D (2004) The Ampelisca aequicornis group of species (Amphipoda: Ampeliscidae) with a key, and a description of Ampelisca eclimensis sp. nov. from Ireland. J Mar Biol Ass UK 84:155-164

Lourido A, Moreira J, Troncoso JS (2008) Assemblages of peracarid crustaceans in subtidal sediments from the Ría de Aldán (Galicia, NW Spain). Helgol Mar Res 62:289-301

Marques JC, Bellan-Santini D (1991) Gammaridea and Caprellidea (Crustacea-Amphipoda) of the Portuguese south-western continental shelf: taxonomy and distributional ecology. Bijdrage Dierk 61:65-87

Marques JC, Bellan-Santini D (1993) Biodiversity in the ecosystem of the Portuguese continental shelf: distributional ecology and the role of benthic amphipods. Mar Biol 115:555-564

Martínez J, Adarraga I (2003) Estructura y evolución temporal de los sedimentos y de las comunidades bentónicas afectadas por los vertidos de un colector de aguas residuales en San Sebastián (Guipúzcoa) (golfo de Vizcaya). Bol Inst Esp Oceanog 19(1-4): 345-370

Martínez J, Adarraga I, Ruiz JM (2007) Tipificación de poblaciones bentónicas de los fondos blandos de la plataforma continental de Guipúzcoa (sureste del golfo de Vizcaya). Bol Inst Esp Oceanog 23(1-4):85-110

Moreira J, Gestoso L, Troncoso JS (2008a) Diversity and temporal variation of peracarid fauna (Crustacea: Peracarida) in the shallow subtidal of a sandy beach: Playa América (Galicia, NW Spain). Mar Ecol 29(1):12-18

Moreira J, Lourido A, Troncoso JS (2008b) Diversity and distribution of peracarid crustaceans in shallow subtidal soft bottoms at the Ensenada de Baiona (Galicia, N.W. Spain). Crustaceana 81:1069-1089

Moreira J, Aldea C, Troncoso JS (2010) Temporal dynamics of gastropod fauna on subtidal sandy sediments of the Ensenada de Baiona (NW Iberian Peninsula). Helgol Mar Res 64:311-320

Myers AA, McGrath D (1991) The Ampelisca diadema group of species (Amphipoda: Gammaridea) in British and Irish waters. J Mar Biol Ass UK 71:265-279

Poggiale J-C, Dauvin J-C (2001) Long-term dynamics of three benthic Ampelisca (Crustacea-Amphipoda) populations from the Bay of Morlaix (western English Channel) related to their disappearance after the 'Amoco Cadiz' oil spill. Mar Ecol Prog Ser 214:201-209 
Ramos-Gómez J, Martín-Díaz ML, DelValls TA (2009) Acute toxicity measured in the amphipod Ampelisca brevicornis after exposure to contaminated sediments from Spanish littoral. Ecotoxicology 71:265-279

Reid DM (1951) Report on the Amphipoda (Gammaridea and Caprellidea) of the coast of tropical West Africa. Atlantide Report, Sci Res Danish Exped Coasts Trop W Afr 1945-1946(2):189-291

Schellenberg A (1925) Crustacea VIII: Amphipoda. Volume 3. In: Michaelsen W (ed) Beitrage zur Kenntnis der Meeresfauna Westafrikas. L. Friedrichsohn \& Co, Hamburg, pp 111-204
Wakabara Y, Kawakami E, Tararam AS (1982) Amphipods as one of the main food components of three Pleuronectiformes from the continental shelf of South Brazil and North Uruguay. Mar Biol 68:67-70

Walker AO (1904) Report on the Amphipoda collected by Professor Herdman, at Ceylon, in 1902. Ceylon Pearl Oyster Fish Suppl Rep 17:229-300 